metabolic balance subsequent diabetic management in more conventional forms will be more successful.

Brittle diabetes is remarkable difficult to manage and totally disrupts the life of the patient. Long-term continuous intravenous infusion of insulin using a small portable system allows acceptable metabolic control to be achieved when other methods have failed.

I thank the patient for her cheerful co-operation, the nursing staff of Pinewood Ward for their enthusiastic help; Miss J R Tomlinson for her secretarial help; Dr Kurtz of the Cobbold Laboratories, Middlesex Hospital, for measuring free insulin concentration and insulin binding; Miss A Mansfield for inserting the catheter; and Dr G P Blanshard for allowing me to report on his patient.

\section{References}

1 Watkins PJ. Insulin infusion systems, diabetic control, and microvascular complications. Br Med f 1980;280:350-2.

2 Pirart J. Diabetes mellitus and its degenerative complications: a prospective study of 4400 patients observed between 1947 and 1978 Diabetes Care 1978;1:168, 252.

${ }^{3}$ Pickup JC, Keen H, Parsons JA, Alberti KGMM. Continuous subcutaneous insulin infusion: an approach to achieving normoglycaemia. Br Med f 1978; : 204-7.

+ Pickup JC, White MC, Keen H, Kohner EM, Parsons JA, Alberti KGMM. Long term continuous subcutaneous insulin infusion in diabetics at home. Lancet $1979 ;$ ii :870-3.

5 Pickup JC, Keen H, Parsons JA, Alberti KGMM. Continuous subcutaneous insulin infusion: improved blood glucose and intermediary metabolic control in diabetes. Lancet 1979; i:1255-8.

${ }^{6}$ Tamborlane WV, Sherwin RS, Genel M, Felig P Reduction to normal plasma glucose in juvenile diabetes by subcutaneous administration of insulin with a portable infusion pump. $N$ Engl f Med 1979;300:573-8.

7 Tamborlane WV, Sherwin RS, Genel M, Felig P. Restoration of normal lipid and amino acid metabolism in diabetic patients with a portable insulin infusion pump. Lancet $1979 ; \mathrm{i}: 1258-61$.

' Pickup JC, Home PD, Bilous RW, Keen H, Alberti KGMM. Management of severely brittle diabetes by continuous subcutaneous and intramuscular insulin infusions: evidence for a defect in subcutaneous insulin absorption. $\mathrm{Br} \mathrm{Med} \mathcal{F} 1981$;282:347-50.

${ }^{9}$ Berger M, Halban, PA, Girardier L, Seydoux J, Offord RE. Absorption kinetics of subcutaneously injected insulin: evidence for degradation at the injection sites. Diabetologia 1979;17:97-9.

${ }^{10}$ Anonymous. Subcutaneous injections and absorption of insulin. Lancet 1980;i:1005-6.

${ }^{11}$ Friedenberg GR, White N, Cataland S, O'Dorisio TM, Sotos JF, Santiago JV. Diabetes responsive to intravenous but not subcutaneous insulin: effectiveness of aprotinin. $N$ Engl $\mathcal{F}$ Med 1981;305:363-8.

12 Nakagawa S, Nakayama H, Sasaki T, et al. A simple method for the determination of serum free insulin levels in insulin treated patients. Diabetes $1973 ; 22: 590-600$.

${ }^{13}$ Kurtz AB, Matthews JA, Mustaffa BE, Daggett PR, Nabarro JDN. Decrease of antibodies to insulin, pro-insulin and contaminating hormones after changing treatment from conventional beef to purified pork insulin. Diabetologia 1980;18:147-50.

${ }^{14}$ Heimbach DM, Ivey TD. Technique for placement of a permanent home hyperalimentation catheter. Surg Gynecol Obstet 1976;143:634-6.

15 Bailey MJ. Reduction of catheter-associated sepsis in parenteral nutrition using low-dose intravenous heparin. Br Med f 1979;i:1671-3.

${ }^{16}$ Dandona P, Foster M, Haley F, Greenbury E, Beckett AG. Low dose insulin infusions in diabetic patients with high insulin requirements. Lancet 1978 ;ii :283-5.

${ }^{17}$ Paulsen EP, Courtney JW, Duckworth WC. Insulin resistance caused by massive degradation of subcutaneous insulin. Diabetes 1979;28:640-5.

18 Riella MC, Scribner BH. 5 years' experience with a right atrial catheter for prolonged parenteral nutrition at home. Surg Gynecol Obstet 1976; $143: 205-8$.

(Accepted 26 August 1981)

\title{
Variation in response to cytotoxicity of cigarette smoke
}

\author{
J M HOPKIN, V S TOMLINSON, R M JENKINS
}

\section{Abstract}

The cytotoxic effect of cigarette smoke condensate on human polymorphs was investigated in vitro by the method of vital dye exclusion. Exposure to 1/800 of the smoke from one high-tar cigarette killed a detectable proportion of a population of $10^{6}$ cells. The response among the cells from 40 healthy people varied widely, the percentage of dead cells ranging from $3 \%$ to $66 \%$ and from $17 \%$ to $87 \%$ at exposure levels of $125 \mu \mathrm{g}$ and $250 \mu \mathrm{g}$ cigarette smoke condensate respectively. Differences in individuals' responses were reproducible and unrelated to age or sex or smoking habit. The cells from 10 patients with irreversible obstructive airways disease and probable emphysema were significantly more sensitive than those from 10 patients with no respiratory disability matched for age and smoking habits.

Genetically influenced variation in cellular response to cytotoxicity may be an important determinant of the risk of developing emphysema among smokers.

Department of Medicine, University of Birmingham, Queen Elizabeth Hospital, Birmingham

$\mathrm{J} M$ HOPKIN, MD, lecturer in medicine

V S TOMLINSON, BSC, technician

R M JENKINS, MRCP, medical registrar

\section{Introduction}

Cigarette smoke is the dominant factor in producing lung cancer and emphysema, but many heavy cigarette smokers escape either or both these fates, which suggests that other factors influence outcome after prolonged smoking.

We have shown that individuals vary in their in-vitro cellular responses to DNA damage induced by cigarette smoke, as detected by sister chromatid exchanges. ${ }^{1}$ We have also shown that among smokers this variation in response is related to the risk of developing lung cancer. ${ }^{1}$ These findings are in keeping with the somatic mutational theory of malignant transformation. We report here an investigation into the cytotoxicity of cigarette smoke for human polymorphs to determine whether there was any variation in response and whether this was related to the risk of developing emphysema.

\section{Methods}

Using an automatic smoking machine ${ }^{2}$ we produced cigarette smoke condensates from three popular brands of British cigarettes, one with a high-tar content, one with a middle-tar content, and one with a lowtar content. Each condensate was dissolved in dimethyl sulphoxide $(\mathrm{DMSO})$ at a series of dilutions and stored at $-20^{\circ} \mathrm{C}$ before use. Polymorphs were separated from freshly defibrinated venous blood by sedimentation over Hypaque-Ficoll ${ }^{3}$ and after washing were suspended in samples of $10^{6}$ cells in $1 \mathrm{ml}$ of Ringer's solution. Samples of $10^{6}$ cells were exposed to $5 \mu \mathrm{l}$ of DMSO alone and a series of doses of cigarette smoke condensate each dissolved in $5 \mu 1$ of DMSO. After one hour's incubation at $37^{\circ} \mathrm{C}$, when no cell lysis had occurred, 
we assessed cytotoxicity by counting the number of cells that failed to exclude the vital dye Nigrosin. ${ }^{4}$

Initially we examined the responses of cells from five individuals to a series of doses of condensate from each of the three types of cigarette. Then we used condensate from the high-tar cigarette alone to study the responses of cells from the following groups.

Group 1 comprised 40 healthy subjects aged 20-50 years; 20 were men and 20 women and 20 were smokers and 20 non-smokers.

Group 2 comprised 10 men who were heavy smokers and had clinical, physiological, and radiological evidence of severe, irreversible airways obstruction and probable emphysema.

Group 3 comprised 10 men matched with those in group 2 for age and smoking habits (inhalation, duration, and average consumption) but in whom there was no evidence of respiratory disability. Six had ischaemic heart disease, two peptic ulceration, and two varicose veins.

All subjects in groups 2 and 3 were studied while they were outpatients and their clinical problems were stable. They were all lifelong city dwellers and had worked as skilled or semi-skilled manual workers. Oral medication in the two groups was similar but six of the men with probable emphysema used simple bronchodilator aerosols. Individuals from both groups were tested in matched pairs, and their polymorphs were exposed to the same cigarette smoke condensate throughout the series. The table shows the age, smoking habits, and results of simple ventilatory function tests in these two groups. Differences between the three groups' responses at each level of exposure were tested by the Wilcoxon Rank test.

TABLE I-Age, smoking habits, and ventilatory function in groups 2 and 3

\begin{tabular}{lcc}
\hline & $\begin{array}{c}\text { Group 2 } \\
(\mathrm{n}=10)\end{array}$ & $\begin{array}{c}\text { Group 3 } \\
(\mathrm{n}=10)\end{array}$ \\
\hline Age (years) & 59 & $60 \cdot 1$ \\
Smoking: & 40 & $42 \cdot 1$ \\
$\quad$ Duration (years) & $27 \cdot 4$ & 28 \\
$\quad$ Consumption (per day) & $0 \cdot 98$ & $2 \cdot 92(2 \cdot 8)^{*}$ \\
& $(0 \cdot 55-1 \cdot 2)$ & $(2 \cdot 6-3 \cdot 5)$ \\
Forced expiratory volume (1) & $2 \cdot 87$ & $4 \cdot 21(3 \cdot 9)^{*}$ \\
& $(1 \cdot 3-3 \cdot 9)$ & $(3 \cdot 2-5 \cdot 3)$ \\
\hline
\end{tabular}

*Predicted values for age and height.

\section{Results}

Table II shows the mean responses of cells from five individuals to condensate from the three types of cigarette. Cell suspensions with DMSO alone suffered no loss of cell viability over one hour, but cigarette smoke condensate produced a dose-related cytotoxic effect. The three doses used-50 $\mu \mathrm{g}, 125 \mu \mathrm{g}$, and $250 \mu \mathrm{g}$-represented,

TABLE II-Response of human polymorphs (mean of 5 individuals) to cytotoxicity of smoke condensates from low-tar, middle-tar, and high-tar cigarettes. Results are percentages of polymorphs killed

\begin{tabular}{lccc}
\hline & \multicolumn{3}{c}{ Condensate dose $(\mu \mathrm{g} / \mathrm{ml})$} \\
\cline { 2 - 4 } $\begin{array}{l}\text { Type of } \\
\text { cigarette }\end{array}$ & 50 & 125 & 250 \\
\hline High tar & $9 \cdot 0$ & $18 \cdot 9$ & $44 \cdot 0$ \\
Middle tar & $9 \cdot 6$ & 20.8 & $42 \cdot 7$ \\
Low tar & $11 \cdot 0$ & $16 \cdot 8$ & $40 \cdot 8$ \\
\hline
\end{tabular}

respectively, $1 / 800,1 / 320$, and $1 / 160$ of the smoke from one high-tar cigarette. Although the different types of cigarette produced different amounts of condensate (in the ratio $4: 2: 1$ for high-, middle-, and lowtar categories), the condensate from each type of cigarette produced the same cytotoxic effect.

Cells from the 40 healthy subjects in group 1 showed a continuously distributed variation in response to condensate from the high-tar cigarette, with the proportion of dead cells ranging from $3 \%$ to $66 \%$ and from 17 to $87 \%$ at exposure levels of 125 and $250 \mu \mathrm{g}$ cigarette smoke condensate respectively. Fig 1 shows a representative sample of the cells from eight healthy individuals tested concurrently. The retesting of the responses of 15 subjects from group 1 under different circumstances-split samples tested concurrently, repeat tests after one month, or tests after exposures of 30,60, and 90 minutes-showed that these differences in response were reproducible (table III). An analysis of the results of all 40 healthy subjects in group 1 showed that these stable differences in response were unrelated to age, sex, or smoking habit.

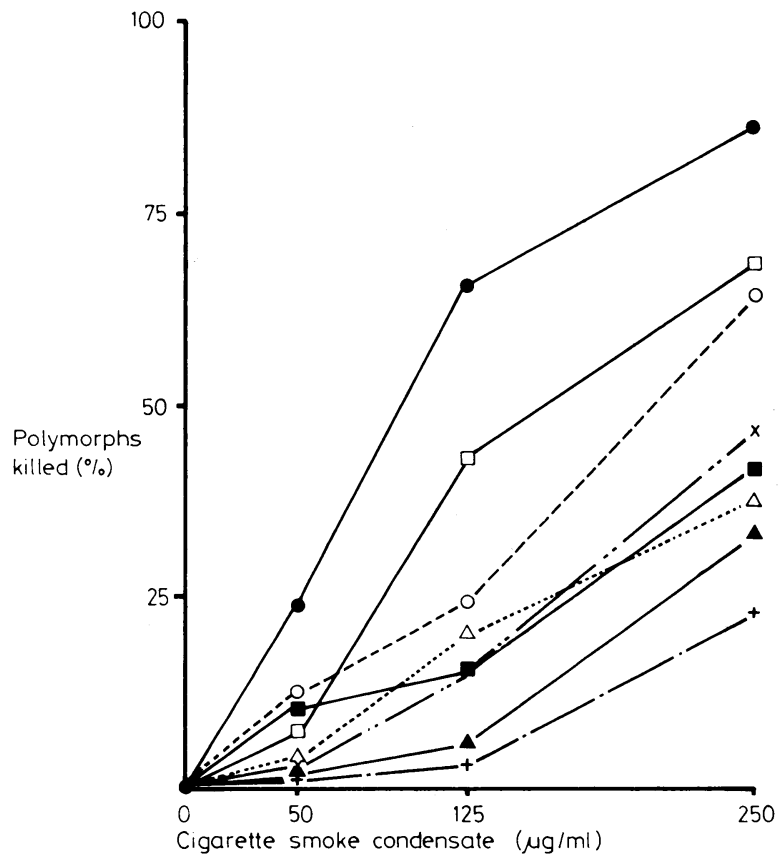

FIG 1-Response of polymorphs from eight subjects from group 1 tested concurrently to condensate from high-tar cigarettes.

TABLE III-Results of testing under different circumstances in group 1. Fifteen subjects were tested and the results in three are shown

\begin{tabular}{|c|c|c|c|}
\hline & \multicolumn{3}{|c|}{ Cigarette smoke condensate $(\mu \mathrm{g} / \mathrm{ml})$} \\
\hline & 50 & 125 & 250 \\
\hline \multicolumn{4}{|c|}{ Split samples tested concurrently } \\
\hline $\begin{array}{l}\text { Case } 1 \\
\text { Case } 2 \\
\text { Case } 3\end{array}$ & $\begin{array}{l}6 \cdot 9 / 8 \cdot 8 \\
4 \cdot 0 / 2 \cdot 7 \\
1 \cdot 7 / 0\end{array}$ & $\begin{array}{c}39 \cdot 1 / 46 \cdot 3 \\
18 \cdot 0 / 13 \cdot 9 \\
2 \cdot 8 / 4 \cdot 2\end{array}$ & $\begin{array}{l}70 \cdot 9 / 65 \cdot 7 \\
54 \cdot 7 / 38 \cdot 8 \\
13 \cdot 5 / 20 \cdot 5\end{array}$ \\
\hline \multicolumn{4}{|c|}{ Repeated tests: original values and those at 1 month } \\
\hline $\begin{array}{l}\text { Case } 1 \\
\text { Case } 2 \\
\text { Case } 3\end{array}$ & $\begin{array}{l}8 \cdot 0 / 6 \cdot 8 \\
7 \cdot 8 / 12 \cdot 1 \\
0 \cdot 8 / 0 \cdot 9\end{array}$ & $\begin{array}{c}18 \cdot 0 / 15 \cdot 9 \\
42 \cdot 5 / 23 \cdot 2 \\
3 \cdot 4 / 7 \cdot 9\end{array}$ & $\begin{array}{l}40 \cdot 5 / 37 \cdot 8 \\
68 \cdot 0 / 52 \cdot 7 \\
17 \cdot 2 / 28 \cdot 2\end{array}$ \\
\hline \multicolumn{4}{|c|}{ Dose response tests } \\
\hline $\begin{array}{l}\text { Case } 1 \\
\text { Case } 2 \\
\text { Case } 3\end{array}$ & $\begin{array}{r}24.0 \\
12.9 \\
0.8\end{array}$ & $\begin{array}{r}65 \cdot 7 \\
24 \cdot 1 \\
3 \cdot 4\end{array}$ & $\begin{array}{l}86 \cdot 3 \\
63 \cdot 8 \\
17 \cdot 2\end{array}$ \\
\hline \multicolumn{4}{|c|}{ Time response tests: dose $250 \mu \mathrm{g} / \mathrm{ml}$} \\
\hline $\begin{array}{l}\text { Case } 1 \\
\text { Case } 2 \\
\text { Case } 3\end{array}$ & $\begin{array}{c}30 \mathrm{~min} \\
64 \cdot 7 \\
27.8 \\
4.0\end{array}$ & $\begin{array}{c}60 \min \\
86 \cdot 3 \\
63 \cdot 8 \\
17 \cdot 0\end{array}$ & $\begin{array}{c}80 \min \\
98 \cdot 1 \\
87.6 \\
43.0\end{array}$ \\
\hline
\end{tabular}

Fig 2 shows the responses of cells from groups 2 and 3 after exposure to the three doses of cigarette smoke condensate. Cells from neither group lost viability in suspensions exposed to DMSO alone but cigarette smoke condensate produced a dose-related cytotoxic effect. There was some overlap between the two groups at each level of testing, but as a group the controls (group 3) were more resistant to the cytotoxic effect of cigarette smoke, and this finding was consistent and significant at each level of testing $(p<0 ; 01)$. There was no difference in response between the patients with emphysema who used bronchodilator aerosols and those who did not.

\section{Discussion}

This study showed that cigarette smoke is a potent cytotoxic agent. The effect of the smoke was detectable in a population of 
$10^{6}$ polymorphs exposed to $50 \mu \mathrm{g}$ of cigarette smoke condensate -a quantity derived from $1 / 800$ of the smoke from one high-tar cigarette. The cytotoxicity of the condensate from the filtered cigarettes (middle- and high-tar categories) was the same as that from the unfiltered high-tar cigarette, which reinforces recent evidence that filter cigarettes are safe in only a limited sense. ${ }^{5}$

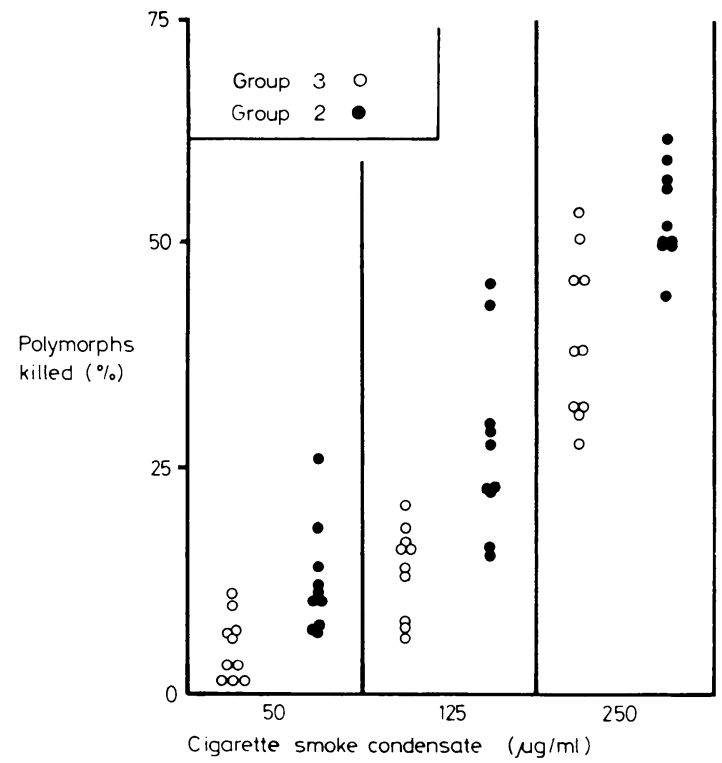

FIG 2-Responses of polymorphs from groups 2 and 3 . Horizontal lines show mean values.

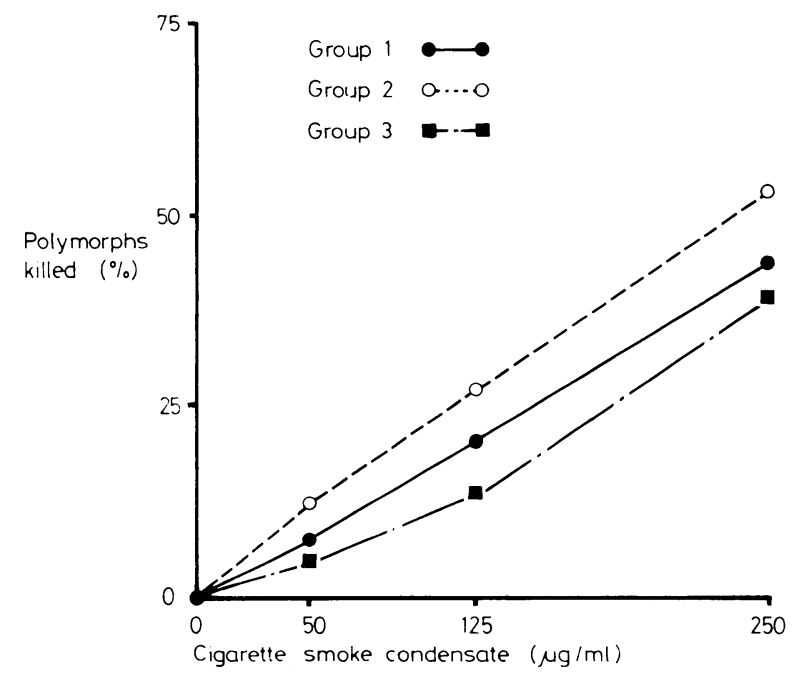

FIG 3-Mean responses of polymorphs from groups 1, 2, and 3.

Comparison of our two highly selected groups (2 and 3) with our younger healthy group (1) showed that none of the individual responses from the selected patients fell outside that found in the healthy group. The responses of the patients with probable emphysema (group 2) and of their heavily smoking controls (group 3) clustered at either end of the spectrum of normal responses. We have no evidence to suggest that the responses of the patients with emphysema were secondary to their disease, with its low grade inflammation. The responses of a fourth group of patients with acute infective and chronic suppurative disease of the chest and inflammatory disorders of other systems showed that their cells were more, rather than less, resistant to the effects of cigarette smoke than those of the other three groups tested, which may reflect the presence of younger, more metabolically active polymorphs in their circulation. Furthermore, the finding that the cells of the heavy smokers in group 3 (who had no respiratory disability and no active disease) were more resistant than those of the healthy unselected group strongly supports the conclusion that the differences in responses between our two highly selected groups ( 2 and 3 ) were primary.

Our results therefore support the epidemiological evidence that many heavy smokers can escape the development of emphysema, but suggest that this may not be by the effect of chance alone but, in a proportion of individuals, because their cellular responses differ from those of their emphysematous counterparts. Our findings also accord with the current theory of the development of emphysema, which states that polymorphs in the lungs that have been damaged by cigarette smoke release proteolytic enzymes which initiate the pathological process by digesting supporting tissues in the lung. ${ }^{6}$ Exposure of polymorphs from the peripheral blood to cigarette smoke condensate in vitro results in significant release of elastase and a loss of cell viability. ${ }^{7}$ Our results suggest that individuals whose cells are more sensitive to cigarette smoke would release more of the damaging enzyme and suffer greater lung damage than their more resistant counterparts.

The origin of the continuously distributed variation in individuals' responses is probably multifactorial. The stability of individuals' responses and evidence from epidemiological studies of a significant familial effect on the risk of emphysema ${ }^{8}$ suggest that genetic factors are probably important. These conclusions parallel those that we have made about the variation in response to the mutagenicity of cigarette smoke and the risk of lung cancer, and are hardly surprising in view of the complex events examined, involving many cellular proteins, and in view of the outbred and diverse nature of man as a species, in whom there is increasing evidence of high rates of genetically determined protein polymorphism. ${ }^{9}$

We thank the Research Department of Imperial Tobacco Ltd for lending us the smoking apparatus.

\section{References}

${ }^{1}$ Hopkin JM, Evans HJ. Cigarette smoke induced DNA damage and lung cancer risks. Nature 1980;283:388-90.

${ }^{2}$ Hopkin JM, Evans HJ. Cigarette smoke condensate damage DNA in human lymphocytes. Nature 1979;279:241-2.

${ }^{3}$ Ferrante A, Thong YH. A rapid one step procedure for purification of mononuclear and polymorphonuclear leukocytes from human blood using a modification of the Hypaque-Ficoll technique. $\mathcal{F}$ Immunol Methods $1978 ; 24: 389-93$.

4 Kaltenbach JP, Kaltenbach MH, Lyons WB. Nigrosin as a dye for differentiating live and dead ascites cells. Exp Cell Res 1958;15:112-7.

5 Wald N, Doll R, Copeland C. Trends in tar, nicotine and carbon monoxide yields of UK cigarettes manufactured since 1934. Br Med F 1981 ;282: 763-5.

${ }^{6}$ Anonymous. The pathogenesis of pulmonary emphysema. Lancet 1980;i: 743-5.

${ }^{7}$ Blue ML, Janoff A. Possible mechanisms of emphysema in cigarette smokers. Am Rev Respir Dis 1978;117:317-25.

${ }^{8}$ Larson ML, Kueppers F, Fudenberg HH. Genetic and environmental determinants of chronic obstructive pulmonary disease. Ann Intern Med 1970;72:627-32.

${ }^{9}$ Harris H. Enzyme protein polymorphism in human populations. $\mathrm{Br} \mathrm{Med}$ Bull 1969 ;25:5-13.

(Accepted 11 September 1981)

MISERABLE indeed is the lot of man in the ftate of infancy. He comes into the world more helplefs than any other animal, and ftands much longer in need of the protection and care of his parents; but, alas! this care is not always beftowed upon him; and when it is, he often fuffers as much from improper management as he would have done from neglect. Hence the officious care of parents, nurfes, and midwives, becomes one of the moft fruitful fources of the diforders of infants.

(Buchan's Domestic Medicine, 1786.) 